\title{
Sociocultural Aspects of Technological Change The Rise of the Swiss Electricity Supply Economy
}

\section{Journal Article}

Author(s):

Gugerli, David

Publication date:

1995

Permanent link:

https://doi.org/10.3929/ethz-b-000048342

Rights / license:

In Copyright - Non-Commercial Use Permitted

Originally published in:

Science in Context 8(3), https://doi.org/10.1017/S026988970000212X 
DAVID GUGERLI

\section{Sociocultural Aspects of Technological Change: The Rise of the Swiss Electricity Supply Economy}

\section{The Argument}

The impressive growth of the Swiss electricity supply industry in the late nineteenth century has usually been explained by Switzerland's abundant waterpower resources, its well-equipped financial markets, and the mechanical skills of its Swiss workers and engineers. This article does not aim to deny the importance of these factors. Rather it seeks to explain how they developed synergetic effects and how they were knit together. The argument is put forward in three steps: First, I show the importance of the new technology's discursive integration, arguing that the development of a specialized electric discourse led to a social shaping of technology that was highly compatible with generalized cultural patterns of late nineteenth-century Swiss society. The expressive dispositions and instituted means of expression that constitute the electric discourse were constantly pursuing and achieving effective resonances in other discursive fields. This allowed for a solid integration of the electrotechnical discourse in late nineteenth-century Swiss society.

Second, I argue that electrotechnology was modeled in such a way that it became coupled with existing technological (and scientific) practices, such as the national mapping endeavor, the urban gas and water supply, the sewer system, and the telegraphic networks. It is noteworthy that making electrotechnology compatible with other technological practices led not only to similar patterns in the design and management of both the old and the new technologies but also to direct links among them: in several cities electric generators were built into and operated with the existing water supply station.

Using the example of the electrification of Zurich, I then, in a third step, combine the two elements - discursive accommodation and practical assimilation - to demonstrate their effects on the selection and construction of technology. The article's somewhat complex argumentative strategy allows for a differentiated interpretation of the phenomenon and shows the importance of taking into consideration the sociocultural dimension of technological development if we want to understand the driving forces of an economic growth that had its roots in the diffusion of a new technology. 
It has never been difficult to construct a seemingly smooth explanation for the rise of Switzerland's electricity supply industry. Historians could point to the high level of know-how among both engineers and skilled workers, to Switzerland's abundant unexploited waterpower, and finally to the country's well-equipped institutional financing system. When confronted with empirical evidence, however, this interpretation stands in need of serious reconsideration: First, the know-how of Swiss engineers and technicians did not really play an overwhelming role in the initial phase of electrification. The technology was, in fact, mainly borrowed from foreign patent holders and inventors. Likewise, the founding history of the famous Brown, Boveri, and Co. in Baden shows that labor skill was considered to be of marginal importance (Ziegler 1937, 18). Second, to treat the availability of waterpower as a driving force in Switzerland's electrotechnical development is to repeat a contemporary myth in an uncritical way. The argument does not take into account the fact that many countries had waterpower resources available but did not electrify in the nineteenth century. Thus historians substitute a necessary for a sufficient condition, as if the Silicon Valley boom had its roots in the relatively easy access of California entrepreneurs to the international silicon markets. Third and most surprising, the capital for the powerplant construction boom of the early 1890s did not come from institutional investors; it was provided either by small middle-class shareholders or by communities that had to justify their investments in electricity supply utilities to the voting public. Electrification as a popular movement? In fact, the Swiss public was obsessed with electricity. Public events such as the National Exhibition of 1883 in Zurich and the Frankfurt Electrotechnical Exhibition of 1891 had mobilized thousands of enthusiasts, and they eventually represented the political and economic bases for the first boom in the construction of powerplants during the early 1890s - i.e., several years before the country's banks started to consider investing in the electricity supply economy of Switzerland. Despite the astonishing reluctance of the bankers to invest in the electrical sector, in 1895 Switzerland already had well over seventy operating power plants, and their generating capacity had reached its highest annual growth rate in history ${ }^{1}$ (see below, figure 1).

Given the widespread popularity of electricity, one would like to know why the Swiss public had become susceptible to the new technology and how this enthusiasm finally led to high growth rates in generating capacity. How did the excitement about the new technology narrow technological contingencies, and how was it channeled into a collectively sustained agreement about the future of electrotechnology?

A simple explanatory model could seek to show that a collective consensus was achieved mainly through top-down manipulation of potential small investors by

1 On the absence of bank investments, see Neue Zürcher Zeitung (hereafter NZZ), 2 November 1893; and Bericht über Handel und Industrie im Kanton Zürich, 1895, 121. See also Wyss 1964; Grossmann 1918. On the number of operating power plants, see Wyssling 1946, 174-83. 
the nation's political and economic elite (see Zimmerman 1992, which describes electrification as a system of governance; see also Zängl 1989). However, this would imply a previous unification of expectations within the elite, including (among others) the executive boards of the Swiss banks. The banks' reluctance to invest as well as the federal parliament's lack of interest in establishing a coherent body of legislation on electricity in the early 1890 s do not favor such an interpretation (cf. Schär 1905). On the other hand, recent studies in the field of sociotechnical change concentrate rather on the social construction of technological systems, on the latter's interpretative flexibilities, and on sociotechnical debates and their "closures."This model implies the existence of competitive, controversial interpretations of "the electric," each of which must be connected with the interests of a peculiar social group (Bijker et al. 1987; Bijker and Law 1992). Yet the startling absence of any opposition to electrification projects in Switzerland before the 1920s makes the social construction approach just as unhelpful.

As an alternative for these explanations I propose to have a closer look at the contemporaneous formation of electrotechnical discourse and practice (see Gugerli 1994a and forthcoming c). In this paper I will develop a new perspective on the issue, mainly by discussing the intertwining or packaging of three equally important dimensions of technical development. First, the discursive configuration of electrotechnology; second, the conditions of technological practice that preceded and accompanied electrotechnology in late nineteenth-century Switzerland; and, third, the "social construction of technology" as a process of selection determined both by social and political forces and by the technical utility and cultural significance of electricity in Switzerland.

\section{Electrifying Switzerland: The Discursive Configuration of Electrotechnology}

In January 1895, Johannes Pernet of the Swiss Federal Institute of Technology gave a public talk on electricity. In the physics lecture hall he set up several electrical devices in preparation for his popular demonstrations and waited for the audience to arrive. What happened then must have surpassed the lecturer's wildest expectations: people virtually stormed his lecture hall. Nearly four times as many people as got into the hall remained outside the building, unable to catch a glimpse of even a single electric arc. Pernet had to repeat his talk the same evening, and the organizers of the lecture decided to offer weekly lectures. To prevent further turmoil, they distributed "free entrance tickets among the friends of electrotechnology" (NZZ, 21 January 1895). Several hundred of those friends, however, failed to get a ticket, as all were given away within hours. One newspaper commented a few days later:

This experiment demonstrates the strong demand for popular-scientific lectures.... It's gratifying that our young workers are not just interested in 
playing cards, sports, and political agitation. Mister Pernet knows how to grab his audience through his clear, generally understandable performance. Supported by the excellent devices and installations of his lecture hall, he provided his audience, composed of people of all ranks and ranges of education, with a clear notion of the elements of electrical science. (NZZ, 24 January 1895). ${ }^{2}$

Pernet's (and others') talks about electricity informed a wide public about electrotechnical questions and have to be understood as a means to create general acceptance among present and future consumers of electricity. This popularizing discourse, however, also fell on the fertile soil of a language of "progress," "network growth," "expansion," "increased domination," and "modernity,"which had been produced by the double process of unifying Swiss politics and humanizing Swiss nature. Since the late 1880 s both discursive strains had become part of the electric discourse. This discourse depended very much on its ability to find resonance in other group-specific discourses. The incorporation of the electric discourse into the unified nation's "federal language," and its allusion to other technological practices that helped to standardize nature, formed a very strong alliance and committed a broad range of social groups to participating in this discourse. Without its great public appeal, and without the support of the mass media of different political colors, this discourse would not have spread so rapidly across class barriers. The highly coded semantic was guaranteeing both standardized patterns of perception and a sufficiently fixed consensus on the future of electricity and its applications.

However, neither the electrotechnical discourse nor the productive capacity of the Swiss power plants had a uniform, continuous development. Irregular annual growth rates of accumulated electricity-generating capacities characterize the first fifty years of electrical development in Switzerland. It is noteworthy, that each downswing provoked an intensified public debate and produced a new discourse on fundamental issues of the political economy of the Swiss electricity supply industry (see figure 1). Such fundamental debates occurred (a) around 1890, on the transmission and distribution of electricity (Gugerli 1994b); (b) between 1900 and 1902 , regarding expropriation rights for the construction of power plants and electricity transmission lines, closing with a federal law on electric power (Meili 1900); (c) during World War I, on the nationalization of waterpower (Amt für Wasserwirtschaft 1916); the electrification of the national railway system, and the foundation of state-owned powerplants (Imhof 1925; Trüb 1922); (d) on quotas for export of the national electricity production to neighboring countries (Vereinigung exportierender Elektrizitätsunternehmungen 1976); (e) on the electrification of the household in order to reduce overcapacities in the early and late 1920s (Bütikofer 1921); and (f) on rural electrification in the 1930s (Günthart 1936).

2 All quotes have been translated by me either from German or from French. 


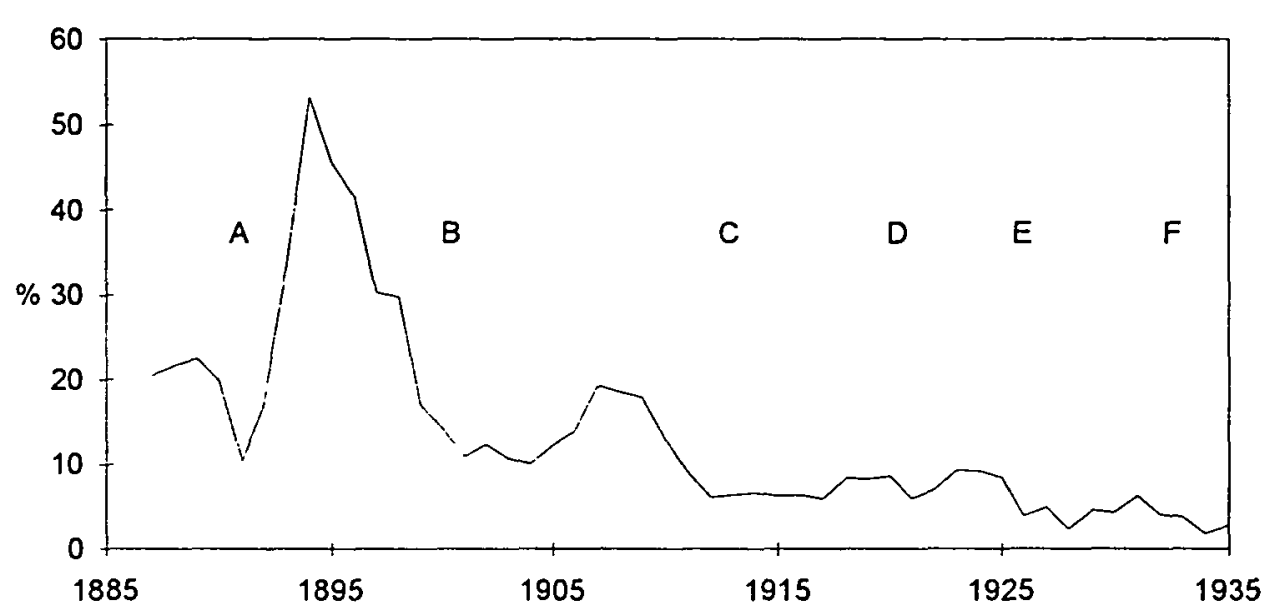

Figure 1. Annual growth rate of total Swiss electric powerplant capacity, 1886-1936 (3-year moving average). Source: Wyssling 1946, 498.

Hence each of the growth rate's downswings coincided with an apparent need for sociotechnical and discursive reorientation. The literal discursive tides or fundamental debates during the downswings led, after their closure, to reassure the investors (private or public). In turn, they established new patterns of consumption that led to an accelerated growth of the generating capacities of the Swiss electricity supply industry (on closure, see Pinch and Bijker 1987, 44-46). Such fundamental debates formed an important condition and a main directive force for electrotechnical growth in Switzerland.

In contrast, Pernet's talk formed part of what I would call a "base discourse," which imbued its audience with a general feeling of competence in dealing with electricity in everyday life. Sustained by a broad network of public talks, general information on electric issues in the press, and literature emanating from the electricity supply industry, it laid the foundation for the general acceptance of electric utilities and their property rights. Both the base discourse and the fundamental debates incorporated electric technology into the sociopolitical and cultural framework of nineteenth- and early twentieth-century Swiss society.

The enthusiasm of Pernet's audience for the electric, which transcended all class barriers, was not unique. The base discourse achieved its popularity through many different channels. The Frankfurt electrical exhibition of 1891, with its over a million visitors, might have been limited in access to the wealthy techno-pilgrims. Nevertheless, during the 1890 s there were countless occasions for everybody to listen to talks on electricity in Switzerland, even in small towns like Langenthal, Andelfingen, Wetzikon, or Döttingen (see NZZ, 18 August 1892; Kopp 1893; Bleuler-Hüni 1903). ${ }^{3}$ Wherever the Charitable Society, the Machinists' and Boil-

3 "The county of Zurzach and especially the region of the lower Aare are observing with great 
ermen's Association, the Liberal Organization, the Technical Society or the Commercial Society advertised a lecture on electrotechnical questions, the hall was filled to the last seat (NZZ, 18 August 1892; Kopp 1893; Bleuler-Hüni 1903). ${ }^{4}$

Furthermore, since the beginning of electrical development, every kind of federal or state celebration represented an excellent occasion for electrical demonstrations. Choral festivals, shooting matches, anniversaries of medieval battles in short, not a single patriotic event took place without dazzlingly bright arc lamps. In the collective memory, national exhibitions represented the climax of these scattered demonstrations. I quote from a report on the Swiss National Exhibition of 1883:

In front of the industrial hall was a square, in the middle of which a fountain with some twenty water jets was booming. At some distance from this water spectacle, five electric arcs hung from each of the two high poles. At nine o'clock these lamps flashed their white light over the square. Now the scene became fairylike.... The eye reveled in these majestic pictures.... Since the atmosphere was elevated anyway, the music underscored the patriotic atmosphere and expressed it with a potpourri of national melodies. (NZZ, 15 May 1883)

Even years after the event, people were talking about the "irresistible attraction exercised by the magic flow of light poured over the festival ground and the fountain"(Burkhard-Streuli 1890,8). In subsequent national exhibitions, electricity represented one of the main attractions, with demonstrations of big multiphase generators in Geneva's 1896 exhibition and electric locomotives in Bern's 1914 exhibition. In Zurich's exhibition of 1939, electricity reached another peak of popularity. High-voltage experiments, an electrically driven waterfall, and an idealized hydrotopographic model of the Swiss landscape were admired, and the public could even ride on little boats through a park of hydropower metal monsters - i.e., the huge Kaplan and Pelton turbines presented by Escher \& Wyss (see Exposition Nationale Suisse 1898; Bauer 1914; for the integration of national exhibitions into the company's marketing strategy, see Maschinenfabrik Oerlikon 1914; see also Lusser 1939, 321-22; Bauer 1939, 287-306).

The festive union of nationalistic self-representation and industrial pride, information and entertainment, presented the products of both the electricity supply industry and manufacturers of electrical devices or machines with the patina of a

\footnotetext{
interest the progress of the big electric power plant in Beznau. On account of the new plant one expects an economic upswing for the whole region. In order to provide the public with some orienting information, the chairmen of the Charitable Society of the County of Zurzach invited the public last Sunday to an informal meeting in Döttingen. The meeting was very well attended, and the hall of the 'Ochsen' [the local inn] was crammed with people." NZZ, 8 February, 1900.

4 "The talk of Director Emil Huber in Oerlikon on newer electric applications, which was organized by the Commercial Society of Zurich, was so well attended that many people could not find a seat" (NZZ, 4 December 1896).
} 
national exhibition. Through such national exhibitions BBC, Escher \& Wyss, Rieter, Cudnod et Sautter, Bürgin and Alioth, Landis and Gyr, Sprecher \& Schuh, Huber \& Suhner, Kummler \& Matter, to name only a few, introduced themselves to a wider public as integral parts of Swiss electrotechnical culture (Landry 1939, 286). Most of them have preserved to this day a solid "corporate identity." Exceptions, like the symbolically painful decline of the old $\mathrm{BBC}$, prove this fact ex negativo (see Catrina 1991).

Even those who could not participate in public shows, those who did not visit the national or international exhibitions, were provided by the daily press with a huge amount of information concerning electrical development. The Landbote, the Neue Zürcher Zeitung, the Bund, the Vaterland, the Journal de Genève, the Feuille d'Avis in Lausanne, as well as smaller newspapers, continuously discussed questions of public electricity supply utilities and presented new applications for electricity in industry, workshop, agriculture, and household. The 1903 report on business and industry claimed that "all social classes of the population" showed "a vivid interest" in electrotechnology. "Everybody is trying to become familiar with the nature of electricity," the report claimed (Bericht über Handel und Industrie im Kanton Zürich, 1903, 148).

The way electric technology became popularized is surely the key to understanding the extraordinary fascination large parts of Swiss society felt for the new technological paradigm. I would argue that the lack of popular opposition to electrification was due to the swift and strong injection of ideology into the electrotechnical discourse. During the 1880 s, this discourse had already started to shape electric technology through a series of locutions that became systematically organized around a small number of commonplace notions such as "the utilization of unexploited waterpower," utility, and progress.

It is very difficult to find contemporary reflections on the shaping of this discourse. Only a few publications indicate its significance, and then only where people are trying to develop an antidiscourse. Among such publications we find papers defending the position of the old gas companies, writings against powerplant projects, or speeches of federalist members of parliament who feared that additional centralization would enhance the ability of the federal government to decide questions for the electricity supply industry (Schilling 1885). ${ }^{5}$ On the whole, however, the huge discursive power of the electricity supply industry took place beneath the threshold of conscious perception. Hence the only way to apprehend its formation is to study its notions, commonplaces, and arguments. This will

5 "It's an unpleasant phenomenon of our time that technicians permit themselves to judge esthetic questions and very often claim that their technical endeavors do not disturb nature's beauty but that they rather embellish nature - as if this could possibly be! - or that they are at least creating new beauty, instead of simply saying: we demand this railway or this power plant for economic and technical reasons, regardless of the detriment to natural beauty. The latter must give way as of minor importance. Thus the battleground is shifted very cleverly to the realm of taste"(Fuchs 1910, 27). See also the debate in parliament on the waterpower legislation of 1915-16. 
explain also why the electrotechnical discourse met with little substantial opposition until the 1920 s.

One of the most successful and most important notions was Gemeinnützigkeit (utility or common good). This was particularly convincing because it could be used and interpreted in a sufficiently obscure and flexible way. On the one hand, public utilities as such were called gemeinnützig, which implied popular access to the services of public utilities. On the other hand, every kind of entrepreneurial activity could be called gemeinnützig since it promised to raise the standard of living within a community (cf. the critical remarks in Pfleghart 1904, 60-61). Furthermore, the notion addressed central elements in the sociopolitical ideology of both liberal and democratic circles. Hence electricity supply companies generally sailed under the flag of Gemeinnützigkeit, whatever they or the voting (and paying) political community meant by this notion. The electricity supply industry was supported very early by the Neue Zürcher Zeitung, the country's most respected newspaper, which upheld and reinforced the officially accepted linguistic terms. In 1891, this newspaper categorically declared: "The general interest [das gemeine Interesse] demands a rapid exploitation of the newly discovered power source" ( $N Z Z, 10$ November 1891). However, it was not only in the financial and economic center of Switzerland that electricity supply was linked to the nation's general welfare. The assembly of the voting men in Glarus, for example, simply declared that any bigger electric power plant had to be considered of public benefit even if useful only for a single entrepreneur, since it was "rendering a service to the industry, the source of welfare" (Amtiches stenographisches Bulletin 1900, 583; see also Pfleghart 1904, 61).

Hence in contemporary semantics Gemeinnützigkeit acquired a generalized and standardized meaning, which included such derived notions as "for the general welfare" or "in the interests of the community." For operating the power plants, this semantic configuration was very important. First, it made waterpower concessions and permits to construct a power plant easier to obtain. Second, it facilitated the tedious construction of transmission lines. In November 1898, the Supreme Court declared: "If private interest is supported by public interest in the execution of an enterprise it is reason enough to declare the right of enforced expropriation. . . Furthermore, the transmission of electricity even for private purposes can be seen as within the interest of the public." Moreover, the Supreme Court's decision maintained that any supply of electric power was in the public interest and served the public welfare "if it generally stimulated and supported the manufacturing and industrial activity of a town" (Wasser- und Elektrizitäts-Werkes Romanshorn 1899, 18).

This view leads us directly to the second important notion in the discourse of electricity, this one centered around waterpower: "Waterpower [was] a national good [that] had to be utilized in the interests of the general welfare of the people and to promote the national economy" (see Amtliches stenographisches Bulletin 1915,170 , session of the Nationalrat [House of Representatives], 20 September 
1915), and it had "to be put into the service of everybody"(Klöti 1905, 27). While the Neue Zürcher Zeitung in 1883 expressed the opinion that there was not enough waterpower available for the illumination of Switzerland's cities $(N Z Z, 1$ June 1883 ), in 1884, H. F. Weber of the ETH pointed to the "masses of water rushing out of the alpine valleys," which represented "mechanical work of a nearly infinite quantity" (Weber 1884, 54). One year later the Schweizerische Bauzeitung wrote that Switzerland did not have coal, "but [the country] has better [things]: more abundant hydropower than any place in Europe" ( 7 March 1885, 59). Finally, in 1888 , the Neue Zürcher Zeitung agreed with this view, claiming that electrification was a great advantage, "especially for Switzerland, poor in coal and almost too rich in waterpower" $(N Z Z, 24$ January 1888). Swiss waterpower resources were thus embedded in the framework of the electric discourse as a source of national independence. In 1900, a deputy in the national parliament emphatically declared during the debate on new electric power legislation: "We should come to a point where not a single drop of water runs from the hills without doing its work for the national welfare. This is a Swiss maxim we must not forget" (Amtliches stenographisches Bulletin 1900,606). As the 1883 point of view of the Neue Zürcher Zeitung demonstrates, this perception of waterpower was not a matter of course. It was the result of an ideological effort that in the discourse of electricity found both its expression and its instrument.

Toward the end of the century, Swiss society widened its demands on waterpower resources. Through electricity, "nature's inexhaustible stocks of energy" had also become "accessible for cultural development." For many writers it was even possible to maintain that "the cultural progress of Switzerland as such" depended on the development of electrical networks (quotes are from the Schweizerische Bauzeitung, 4 July 1896, 1, and 2 January 1904, 4-5). Waterpower, cultural development, and electricity became increasingly intertwined, and the "electrifying" notions of "progress" and "modernity" were discursively bound to the total development of electric technology. The mysterious complexity of technological (and cultural) development was consequently explained by a model of transcendent, irresistible progress. Moreover, "progress" and "modernity" substituted for the lost teleological or eschatological perspective of the future. In the late nineteenth century, they allotted to nature the norms or values of earlier times namely, a source of security (cf. Luhmann 1982, 271-88). Thus progress provided the assurance that an orderly sequence of events would continue into the future, which lessened anxiety about the rapid passage of time. Fears of social complexity or an uncontrollable future were calmed by the establishment of this time-line. Projecting an overwhelming problem as a series of smaller problems seemed to offer the possibility of solving the sequence step by step; the future seen as a sequential developmental process (usually characterized as "progressive" and "modern") stimulated utility-oriented planning activities. The nineteenth-century world had to be a world of planning. Progress, a future reached through predictable steps, could be guaranteed by connecting progressiveness to scientific and technical 
invention ${ }^{6}$ and, simultaneously, by perceiving inventive activity as a human necessity. Even though progress as such could not be calculated, it was characterized by the calculable unknown, which could be proved and secured by making reference to past technological and economic - perhaps even social - "progress" (cf. Koselleck 1975, 410).

In 1887, the Swiss engineer Arnold Bürkli-Ziegler formulated the problem of the calculation of the unknown in electrification as follows: "One can have various opinions concerning the extension of electric illumination in the near future and beyond; but one has to agree that even the most limited initial implementation should be able to be constantly and limitlessly amplified." Nevertheless, this "future expansion" could not be determined right now, "since one would get totally exaggerated numbers, which are very clumsy since there is no guarantee that they correspond to future conditions" (Bürkli-Ziegler 1887,6). On the other hand, the concept of progressive action provided security and reduced the complexity of the contingent present future, i.e., the future as perceived in the present.

The shift from a future loaded with both utopian promise and insecurity toward one of technological progress that legitimized present action even crossed class barriers. It was not only the bourgeoisie and upper class that became convinced of the rectilinear development of society; large parts of the small-business class, the craftsmen, and members of the working class shared this view as well (Müller and Tanner 1988; on the bourgeois middle class in Switzerland, see Brändli 1990, 151-276; and Tanner 1988). Karl Bürkli, for instance, a radical activist in the democratic movement, claimed in 1868: "Our people are swimming in the century's great stream of progress"; while the socialist newspaper Die Tagwacht claimed in 1880: "Machines are the redeemers of mankind, if they are properly used.... In a democratic organization of work and society, machines will be an advantage for everybody.... Hence mankind will reach an unmeasurable cultural level, and the intellectual niveau of the masses will be greatly increased" (both quotes from Müller and Tanner 1988, 336, 334). The late nineteenth century, then, was strongly convinced of the benefit of technological progress and of the progressiveness of technology for the entire society.

Since technological progress was perceived as self-propelled, depending on the invention of engineers and scientists rather than on any kind of political preference or choice, it was also inevitable. There was no way to stop the development of electricity, "the newest progression of the human inventive spirit" (Furrer 1892, 406). Since the early 1880s, hundreds of articles, talks, brochures, pamphlets, scientific newsletters, and introductory readers had connected electrotechnology with "progress" and "modernity"; by 1890 , the terms were nearly equivalent. ${ }^{7}$ Even the legal dogmatists started to defend electricity as legally protected in "modern

6 See the subtitle of the Elektrotechnische Rundschau, Zeitschrift für die Leistungen und Fortschritte auf dem Gebiete der angewandten Electricitätslehre, 1882-; or Beck 1912.

7 The physicist August Kundt claimed in a lecture in 1891: “The day Werner Siemens invented the electrodynamic machine . . . modern electrotechnology was born." Kundt 1891. 
law" and pointed to the "new dangers" to which "the modern world is exposing us with its electric charges and devices." Manufacturing catalogues carried the adjective "modern" in the title - surely stunning proof of the convincing force of the word. 8

The notion of "progress" was even easier to advocate. As early as 1882 , the Zürcher Freitagszeitung called Zurich a "city of progress," since "the entryways of the railway station are now brightly illuminated with electric light." The time "when electric illumination will be introduced in all Zurich is not far off." Moreover, the surrounding towns would promptly be connected with the center by telephone. Concerning electric light, one had simply to wait for the permit to extend the cables from the central station, "so that the hotels and restaurants near the main station, as well as the shops and inns on the Bahnhofstrasse, could be illuminated." The machines were large and powerful enough to make such amplification possible and could "be increased without difficulty," the newspaper claimed (Zürcherische Freitagszeitung, 13 May 1882).

The news article just cited contains all the most important elements of the discourse on progress. The first attempt of private initiative to introduce electrical illumination was concerned with the railway station - the outstanding symbol of modern trade and economy. On 23 May 1882, only ten days after the article was published, the railway line through the St. Gotthard tunnel was officially opened, and one part of it now began from the electrically illuminated hall of the main station in Zurich. Connecting electric light to the Gotthard is significant as a national symbol. The construction of the Gotthard tunnel was one of Switzerland's most important high-tech programs, which finally managed to tame - with the well-coordinated application of modern construction tools, steam power, scientific knowledge, and topographic survey techniques - even the granite of the country's ideological cradle. Zurich, now connected to the world, could receive masses of tourists and direct them to Lucerne or St. Moritz. Zurich seemed to be keeping up even with Paris, London, Vienna, and the hot spot of electric illumination Berlin. And because the hotels had to satisfy international businessmen, electrical illumination became as much a requirement of a decent hotel as the waiter's white gloves and the French card of the maitre de service.

Furthermore, progress, as conceived by the Freitagszeitung, required a telephone network, or at least the general interconnection of the city and its surroundings with a dense network of wires - be they electrical cables or telephone wires. The statement that the time is not far off is very important: progress continues, progress is granted, and progress cannot be stopped. Spare capacities had been reserved, amplification was already planned, and no difficulties were perceived in following progress into the future.

Why this strong concern about time? As will be seen in the second section of this

8 The maxim of Meili 1900 runs: "Electricity is an independent asset of modern law." The previous quote is from Meili 1899, 7. See also Maschinenfabrik Oerlikon 1901. 
paper, nineteenth-century society's attempts to dominate nature were mainly concerned with reshaping the temporal and spatial structure of the natural environment. Furthermore, the process of standardizing nature produced a language of progress and modernity that met the needs of a restructured time model. A discourse configured around "progress" allowed for a reduction of social complexity and amplified the possibilities of communication on such issues as development and planning. Hence it also supported the temporal reshaping of the natural environment by planned technical means. Railways, telegraph lines, hydraulic systems of the rivers and of the cities' undergrounds, telephone wires, and the fast spreading power networks changed the time of nature, while the nature of time was transformed into a model of linear development and planning.

Moreover, electrification itself changed the structure of time on many levels, a process that without doubt had an effect on the semantics of "the electric." Electricity itself was a means to dominate time in the same sense as the electric discourse promoted electrical systems. First, there was virtually no temporal difference between the central production and remote, decentralized consumption of electricity, just as there was no history for generated electricity, since storage devices (accumulators) were only marginally used and generated electricity had to be progressively consumed. Second, natural time limits became increasingly blurred as electric arc lights turned night into day, allowing for a continuous industrial production that was completely independent of any "natural" light; electricity's space of action was open-ended. Third, electric tramways accelerated urban transportation, while small electric motors managed to speed up small workshop production. Accordingly, electricity was a literal means of progressing and growing. Finally, central electric clocks guaranteed a uniform social time in urban contexts. The sweeping fluid movement of their second hands was a perfect representation of nineteenth-century's model of time as a continuous flux (Kern 1893, 20; on space and time as a modern mode of experience, see Berman 1982; and Harvey 1992).

However, the story to be told here is even more exciting. Electrification was not just strongly connected with a progressive model of time, nor was it only shaping late nineteenth-and early twentieth-century temporal structures. The construction of electricity supply networks also promoted discursive networks that in their turn had promoted and would promote new investment and the further expansion of power supply networks. Each village that was connected to the electric grid was also connected to a powerful discursive network. Installation firms started to promote their products, to construct showrooms and electrically illuminated showwindows; each household that received electricity automatically received the utility's propaganda, along with popular versions of federal and cantonal legislation on electric systems (Bertschinger 1914; Stiefel 1935). Hence, in the case of electric power supply, discursive and technical networks had a strong symbiotic relation. 


\section{Conditions of Technological Practice in Nineteenth-Century Switzerland}

The formation of the electrotechnical discourse was intertwined with a large set of contemporaneous technical practices that equally configured the way Swiss society dealt with electrotechnology. If we are justified in speaking, with Pierre Bourdieu, of the habitus, the "embodied history, internalized as a second nature and forgotten as history," if we want to understand this "infinite capacity for generating products - thoughts, perceptions, expressions and actions - whose limits are set by the historically and socially situated conditions of its production," of which one knows that the "conditioned and conditional freedom it provides is as remote from creation of unpredictable novelty as it is from simple mechanical reproduction of the original conditioning," then we should take a closer look at the general characteristics of nineteenth-century Switzerland's technological practices, in order to juxtapose them with the expressive dispositions and instituted means of expression, of which the electric discourse is constituted (see Bourdieu 1992, 54-59). This will prevent us from interpreting the discursive configuration of electrotechnology as a mere ideological or idealistic recording of the electrification process. Discourse and practice will rather appear as two forces that simultaneously shape technology. This view will also enable us to apprehend, as in the third section of this paper, the conditions and the conditioning of the selective processes that eventually led to the social construction of electricity supply utilities in Switzerland.

The way in which nineteenth-century Swiss society usually dealt with nature is best described as a technical and systematic disciplining of nature. While eighteenth-century sciences started to administer nature by constructing systematic nomenclatures, the so-called bourgeois era gave this constructive achievement material form through the creation of technical networks. Thus the natural environment was conquered, separated, and coordinated through technical devices (cf. Walter 1990).

In this management of space, new techniques of cartography, land surveying, and cadastre maps increased the availability of and the control over land and soil. These techniques culminated in the work of the Swiss civil war general GuillaumeHenri Dufour (1787-1875). A recent popular study on Dufour's work goes so far as to compare his military achievements with his topographical and scientific work. Thus the founding father general continued the conquest of his country after 1848 , producing a scientific representation that could be - and actually was offered as a centerpiece of Swiss culture in the country's pavilions at most international exhibitions (Graf 1896,249 ). Dufour and his collaborators virtually covered the landscape with triangulation points defining the outline of a seamless, invisible web that offered the possibility of conquering and representing it scientifically (see Gugerli forthcoming b).

Mapping, however, was just one field of Dufour's engineering activity. In the early 1820s he had also pioneered in the construction of cable suspension bridges (see Peters 1987; Brulhart 1987). It is astonishing how closely Dufour himself 
connected this construction of cable suspension bridges to later topographical work. In 1824 he wrote that "everybody felt the usefulness that this new method of construction could have in a country such as Switzerland, which is cut by rivers and deep canyons that make it often virtually impossible to cross with a normal bridge"(Dufour 1824,4$)$. While his early bridge construction tamed the wilderness of the Swiss landscape and crossed its deep canyons, the survey work achieved the "topographic crossing of the Alps," connected the country with triangulation networks of the neighboring countries, and led to a uniform and scientific representation of Switzerland's natural environment. By gathering the net of triangulation into its coordination center in Bern, Dufour probably held the country together as efficiently as he later did as a politician in the federal upper chamber (on Dufour's topographical work, see Graf 1896).

One of the most important technological achievements of the young confederation was clearly based on Dufour's improvements in topographical surveying. After the founding of the federation in 1848, booming construction activity provided Switzerland with a railway network that created completely new conditions of time and space (see Eidgenössisches Amt für Verkehr 1947-64; for the transformation of space and time through the railroad, see Cronon 1991, 74-81). The transport facilities of the newly connected towns and cities multiplied all at once, while other settlements became relatively less accessible. Since the customs barriers between the twenty-two cantons had been eliminated, moreover, new connections among remote regions of the country started to emerge. This new means of transportation demanded a strongly centralized organization, coordination, and a systematic effort to attain uniformity within the networks of each railway company. Schedules, employee training, fee systems, security devices, and transport capacity were determined mainly by modern, centralized management (see Eidgenössisches Amt für Verkehr 1947-64).

Like the goods and persons that were bundled along on rails, information was channeled through the establishment of telegraphic wire networks. Telegraphs and railways developed a symbiotic relationship, since telegraphs were widely used in the operation of railways, while the railways offered the opportunity to "realize" orders and offers made through the new communication system - i.e., it transported the goods from one side of the country to the other. Because the telegraph system had been under federal control since 1851, it was more centralized and unified than any other contemporary technology (see Federal Law of 23 December, both space and time were technically transformed and gained a new social significance.

Hydraulic engineering joined the rail and telegraph networks in transforming the natural environment and landscape. Wild rivers were forced into straightened riverbeds, swamps were drained, and water levels were carefully monitored throughout the country. The conquest of new, hitherto only marginally exploited, soils through the construction of dams and the digging of drainage ditches transformed the Swiss landscape. The land became easier to exploit, less dangerous, 
and therefore less difficult to administer; in other words, it became civilized and disciplined (Vischer 1986).

While Dufour described the natural spaces of Switzerland cartographically, others followed with a hydrometric description of the same landscape. The director of the Federal Hydrometric Central Office, Robert Lauterburg (1816-1893) published in 1876 a survey of the flow of the Swiss hydrological network (Lauterburg 1876; see also Epper 9107; and Vischer 1988, 1184-91). The importance of this work lies in its presentation of the Swiss rivers as a network, reflecting a totally new perception of the natural environment. In this work, Lauterburg applied his practical experience as a former manager of the local cantonal floodgates near Thun to the entire country. The floodgates in Thun were not only used to manage the lake's water level but also to provide the local shipping companies twice a week with a sufficiently big flood to continue operating even in times of a low water (Vischer 1988, 2). Using scientific methods of measurement and estimation, Lauterburg began to study the effects of those floods along the extended river system. His reshaping of nature, his new perception of Swiss rivers, lakes, glaciers, and precipitation as a network with its own rules and regulative mechanisms provided the fund amentals necessary for making decisions about hydraulic engineering, for calculating the nation's waterpower potential, and for regulating waterpower concessions. Lauterburg's model therefore established control over natural hydrological conditions in Switzerland and helped realign the expectations of entrepreneurs and politicians about the utilization of "unexploited" waterpower (Lauterburg 1891; see also NZZ, 25 June 1891; Jegher 1894; Schär 1905).

Swiss engineers not only tamed wild torrents and high-water rivers; they also attacked the mountains. As Adolf Guyer-Zeller noted, "While only a few decades ago nearly all journeys to the Alps were expeditions of discovery in unknown regions, nowadays the entire world of the Alps has become the accessible common property of the people" $(1896, \mathrm{~V})$. The regularly published "Alpine Chronicle" of the Neue Zürcher Zeitung gives evidence of the wide-ranging conquest of the Alps. On the heels of the pioneers followed the members of the Swiss Alpine Club (all of them well-equipped with Dufour's maps), and after them came the hoteliers, the operating authorities of mountain railways, and finally the international crowd of tourists. "After the Rigi and some smaller lines were clapped in irons, the railways to the Pilatus and the Brienzer Rothhorn followed"(ibid.). ${ }^{9}$ In other words, the "unbound Prometheus" put nature in irons. The construction of mountain railways became a strategy in the industrial conquest of nature, and driven by the alleged "human urge to conquer the summits," tracks, steam power, tunnels, and cogwheels tamed the alpine wilderness. ${ }^{10}$

9 The railway to the Rigi was built in 1871 , and the one to the Pilatus from 1886 to 1889.

10 "The urge to the summits is deeply rooted in the interior of man, and in all epochs the mortals have considered hills and mountains as the holy sites of gods, where they erected them places of worship." Guyer-Zeller 1896, V. See also Allen 1967. On alpine tourism see Bernard 1978; Seitz 1987; Schmidt 1990. 
Meanwhile, down in the flatland, urban authorities were gaining experience in handling complex technological systems. First they had to deal with water supply systems. Reliable regulation of the standards of water quality and the pressures within the mains required management by a centrally directed, politically legitimate authority (see Bürkli-Ziegler 1878).

The second technological system operating in urban networks was the gas supply. Gas supply companies started to operate in cities like Zurich, Geneva, Lucerne, and Basel in the late 1840s. Gas lighting installations transformed the nighttime topography of the cities, separating bright, representative zones of urban life from dark and dangerous districts. Night became increasingly civilized and accessible to the city's bourgeoisie once the illuminating beams of the gas lamps began to eradicate nocturnal shadows and obscure figures (see Zollikofer 1928; Gas-, Wasser- und Wärmeversorgung der Stadt Bern 1993; Schivelbusch 1983).

Finally, two-way telecommunication became available in the larger cities through the introduction of the telephone, which soon spread to the cities' immediate surroundings. For a time, Switzerland became a European leader in telephone technology; its networks probably developed much faster than those of any other European country. The centrally controlled Telegraph Office successfully built telephone networks in Bern (1881), Geneva (1882), and Lausanne (1883); it nationalized the Zurich network in 1886 and started to integrate local networks into a national grid (Bericht über Handel und Industrie im Kanton Zürich 1889, 18; $N Z Z, 17,18$, and 20 June 1881. See also Generaldirektion PTT 1952-62; Stadelmann and Hengartner 1994).

To summarize, systems, networks, and a general attempt to dominate and conquer natural spaces were common technical practices in Switzerland when the first electrotechnical devices showed up in exhibitions, shooting matches, choral festivals, and commemorative events. Dufour's topographical survey, hydraulic engineering leading to Lauterburg's hydrometrical system, the railways, the telegraph, urban water and gas supply utilities, as well as the recent telephone, together formed and represented a genuine part of bourgeois urban technoculture. All these technical developments spread from the cities to the flatland and even over the "frontier" into the hitherto "wild" Alps. And the increasing domination of nature by means of technical networks was supported by a discourse that connected technical innovations to notions of progress, general wealth, and economic growth. The world became adaptive to control and transformation, as facts, values, and standards were inserted into technical, discursive, and social practices (see Lenoir 1992, 160-63). Thus nineteenth-century Swiss society not only favored a network approach in its domination of nature, it also discursively constructed its natural environment as a malleable field that allowed for the virtually infinite growth of technological systems. 


\section{Sociopolitical Selection and Construction of Electrotechnology}

The neo-Schumpeterian discussion of the 1980s has attempted to "model formally economic competition and growth, technical choice and diffusion, and technologically induced fluctuations as an evolutionary process"(Silverberg 1988, 538; see also Nelson and Winter 1982; Dosi 1988). Considerable attention has been devoted to the problem of technology selection. Yet the discussion was concerned only with the selection of finished technology; it paid little attention to the possibility of learning about technology by building and operating protosystems and then scaling them up (Rosenberg 1982, 120-40).

Recent studies in the field of sociotechnical change propose concentrating on the social construction of technological systems (Bijker et al. 1987; Bijker and Law 1992). As a consequence of this theoretical shift, selective processes have almost disappeared from view, even though the definition, acquisition, and application of the criteria of selection, classification, and interpretation and the application of those criteria in contingent situations shape the learning processes that lead to the social construction and shaping of technology (cf. Siegenthaler 1993). I propose that "the rather messy contingencies" (Bijker and Law 1992) of technology, the social world, and the course of history come to "closure" precisely through selective processes. Without criteria of selection there cannot possibly be closure on any kind of debate. However, I will show that these processes of selecting technology are heavily determined by political, social, and cultural factors - i.e., by the habitus - and that they define a sociopolitical strategy for building, operating, and scaling up new technological systems. In Zurich, as we shall see, electrotechnical selections were made in a way that allowed for an incremental strategy of investment.

During the last decade of the nineteenth century, electrical transmission wires began to structure natural space through the formation of sales areas and new types of economic regions. This development did not stem exclusively from the "nature" of electricity, even if it is difficult to perceive the horizon of lost alternatives hidden by the technological selections once they were made. The decision not to build steam-driven block stations as Edison did, the decision to found city-owned electricity supply companies, the selection of alternate current systems rather than direct current systems, the promotion of small electrical motors for small workshops, the decision to renounce large accumulator systems, the substitution of electrified tramways for horse-pulled and steam-driven streetcars - all these processes of selection can be related as much to the political as to the technological and economic necessities of the epoch. One can hardly overemphasize this fact, particularly since the nineteenth century believed both in a theory of the autonomous development of technology and in the unavoidability of progress as the reason and legitimation for technological change. Thus not only in today's sociology but also in nineteenth-century society, processes of selection and their sociopolitical dimensions nearly disappeared from view. 
Using the example of the electrification of Zurich, I will demonstrate the extent to which sociopolitical rather than economic or technical motives led the city's authorities to choose a specific electrical system (see also Gugerli forthcoming a). As we shall see, the social shaping of technology enters even those realms that are normally considered to be within the exclusive province of the competence of technicians. ${ }^{11}$

Early in 1888 , a commission appointed by the city council started to study the question of electrical illumination in Zurich. At this point the so-called battle of the systems was reaching its climax. Unlike engineers in Germany or the United States, Swiss engineers did not make an article of faith out of the selection of AC or DC systems. Nevertheless, there was considerable confusion among the commission members and the community of technicians. The commission was confronted with a great number of inconsistent recommendations, reports, counterreports, and interventions. Even experienced technicians like Bürkli-Ziegler did not know what to make of these different opinions. ${ }^{12}$ Although a paper prepared by the city's engineer preferred an alternating current system, the question of selecting a system caused many discussions within the commission. "Electrotechnicians have been split into two camps and are defending their opinions with rising warmth," commented the Schweizerische Bauzeitung (30 November 1889, 133).

Without going into detail, let me suggest that all the members of the commission had in the end a good deal of information concerning the advantages and disadvantages of both systems (ibid.). They also knew quite well that they did not have to decide which system was "the better one." Their discussion was concerned rather with the question of which system would better satisfy the city's actual and future needs (Burkhard-Streuli 1890,9). ${ }^{13}$ Hence they had to come to an agreement on what role electrical energy was to play and how electricity should be integrated into the existing sociopolitical context. In other words, electricity was to be shaped to fit into the local conditions of Zurich, and the commission had to make a technical selection that was politically desirable (ibid.). For instance, should the city go into competition with its own gas plant, bought only two years earlier from a private operating company, by introducing a new technique of illumination? Would it not be better to leave the whole question up to private initiative? Should electrical illumination completely replace gas or illuminate only the important civic squares and buildings in the inner city? Should the supply of electrically driven motors be considered? Should the city draw its primary energy from the existing waterpower plant, with its very limited capacity, or should it try to set up

11 This section is based on the proceedings of the commission for the preparation of electrical illumination 1888-1890 (Akten der Kommission für die Vorbereitung des elektrischen Lichtes 1888-90).

12 At one time Bürkli favored the DC system (session of 16 August 1890), while shortly before he had vigorously advocated an AC system (session of 28 June 1890). See Protokoll und Akten der grosstadträtlichen Kommission betr. Einführung der elektrischen Beleuchtung 1890.

13 The commission asked the city councils of Berlin, London, and Paris for advice. See their answers in Archives of the City of Zurich V Bc 5 no. 39 (Berlin), no. 40 (London), and no. 41 (Paris). 
various block stations driven by steam power? ${ }^{14}$ In short, the commission had to decide about the future function of electricity within the increasingly complex framework of public utilities. All these selections and recombinations, which allowed for the construction of the "most compatible" electric system, were genuine political decisions. They were roughly outlined in the announcement in August 1888 of a competition calling for the publicly supplied illumination of various widespread points of the city. For instance, the paper asked for the utilization of the existing waterpower plant, either through an enlargement of this plant "or through a waterpower transmission as provided by the local water lines system," whereas the question of small power supply to workshops was considered to be marginal - such motors could be connected to the city's water supply system for small water engines (Archives of the City of Zurich, V Bc 5 no. 65).

Seven of the eleven projects presented to the commission were immediately rejected. ${ }^{15}$ Among those rejected was a project presented by the well-known company of Thomson \& Houston, which was considered "very incomplete on the illumination of houses, which was the main issue in Zurich." Although it fulfilled the requirements of street illumination for a city like Milan, which was accomplished by a large number of lamps in series, it would not fulfill Zurich's needs, the report of the experts claimed (see also Schweizerische Bauzeitung, 3 August 1889, $28-30$ ). Finally the proposals were reduced to four: a pure AC proposal by the Zürcher Telephongesellschaft, a five-wire direct current project by Siemens and Halske, and two mixed AC and DC systems brought in by the Maschinenfabrik Oerlikon and the company of Stirnemann and Weissenbach.

The commission's instructions to the experts stipulated that

apart from costs, the following points are decisive: the effectiveness of the arrangement especially in connection with the given circumstances at hand, the systematic and harmoniously beautiful formation of the device, the ability to respond to any demand for electric light, and a cheap and reliable operation. (Burkhard-Streuli 1890, 17, my emphasis) ${ }^{16}$

The experts in their turn slightly modified these criteria and asked first "which system of electrical illumination ... would be the most appropriate for the circumstances of Zurich." Hence they voted for the adoption of a mixed system:

14 "I repeat that due to the wide spatial extension of the area to become electrically illuminated in the city and its surroundings, we had to refrain from the beginning to set up a block station in the center of consumption and to apply direct current in normal tension because of the high costs of building such a network." Burkhard-Streuli 1890, 24.

15 The following firms presented projects: Crompton \& Co, Chelmsford, England; J. Ehrenberg, Littau-Luzern; Escher Wyss \& Cie., Zurich; Fabrik für elektrische Apparate, Uster; Maschinenfabrik Oerlikon; E. and P. Sée, Lille; Siemens \& Halske, Berlin, with two projects; Stirnemann \& Weissenbach, Zurich, for Ganz \& Cie in [Buda]Pest, F. Schuckert \& Cie in Nürnberg und Gebrüder Sulzer in Winterthur; Thomson \& Houston, Hamburg; Zürcher Telephongesellschaft, Zurich. Burkhard-Streuli 1890, 17-18; Archives of the City of Zurich, V Bc 5 no. 92.

16 The experts were Emil Bürgin from Basel, Théodore Turrettini from Geneva, and G. Veith of the ETH in Zurich. Archives of the City of Zurich, V Bc 5 nos. 82, 83, 127. 
"Direct current for arc lights and alternate current with a limited number of transformation stations for incandescent light, with the capacity of a switch from AC with transformers to DC with accumulators." This arrangement, they held, would satisfy the contemporary conditions in Zurich "and even more for the probable future design of electric illumination" (Bericht der Experten, quoted in ibid., 20 and 21).

In the commission's opinion, Siemens \& Halske's proposal was quite complicated; it was also the most expensive (1.8 million francs). The pure AC project of the Zürcher Telephongesellschaft was the cheapest ( 1 million francs). Yet as noted earlier, the experts' decision for a mixed system had already been made. Among the two mixed systems, the project of Stirnemann \& Weissenbach did not offer the option of operating with accumulators in the future. So the order went to the Maschinenfabrik Oerlikon, which, in collaboration with Escher Wyss \& Cie., was to build a mixed system of four DC and six AC dynamos at an estimated cost of 1.3 million francs.

And what was the end of these deliberations? The Maschinenfabrik Oerlikon built a pure AC network in Zurich. In the proceedings of the city council of 12 August 1891, we find the following explanation for this sudden about-face:

In the city council's talks held on this issue and later on in the special commission of the great city council, it was declared that if adopted, the DC system for public illumination - which was in the end the most adequate from a technical point of view - would make it necessary to construct the whole installation immediately, or at least to lay the wires, even though the street lamps would not be installed for a long time. The [implied] financial consideration led [the commission] completely to abandon the use of DC for public illumination, to supply the electrical street lamps with $\mathrm{AC}$, and to connect them, like the private lamps, to the next transformers. Thus ... one gains a quite important simplification in management ... and the possibility of a progressive implementation of the public illumination system according to desire and necessity. (Proceedings of the City Council, 12 August 1891, Archives of the City of Zurich, V Ba 5 no. 574, my emphasis)

This justification leads right back to the original public call for offers: "The disposition of the device should foster as much as possible the option of its progressive implementation" (Archives of the City of Zurich, V Bc 5 no. 65, 5).

In the fall of 1890 , a credit of 2.3 million francs was given to the city council for the "progressive implementation of the public arc light illumination." Walter Wyssling, an engineer who became the first professor of electrical technology at the Swiss Federal Institute of Technology, ${ }^{17}$ commented that the desire for a

17 Eidgenössische Technische Hochschule, then known as Eidgenössisches Polytechnikum. For an account of the development of electric engineering at this institute, see Eidgenössische Technische Hochschule 1955, 424-40. 
gradual implementation of the installations, based on financial considerations, led to the abolition of DC for public arc illumination "because it would have required the immediate construction of all transmission lines from the central station, whereas the connection of the arc light with the general AC network permitted the construction of individual areas" (Schweizerische Bauzeitung, 7 January 1893, 4).

Apparently, decision makers in Zurich were quite fascinated by the idea of a progressive implementation of public utilities. The same kind of extension also took place in the political arena. The incorporation of eleven nearby towns into the city of Zurich was decided 9 August 1891 , only shortly after the first steps in the city's electrification. The expansion of the city's political and administrative field of activity into the incorporated towns, which signified its population increasing from 28,000 to 121,000 , depended heavily on the city's ability to offer public utilities that could not have been provided by the former independent small towns around Zurich. Among the most attractive potential advantages of an amplified city were such public services as electricity supply, water supply, gas supply, and public transportation. The last became electrified just after the political incorporation of the surrounding towns. ${ }^{18}$ I quote from an article of Emil Huber, director of the Maschinenfabrik Oerlikon:

Only through the network of tramways will the people of Zurich participate in the benefits of their city; only then will even the former suburbs join with their center, the old city, when a network of traffic veins will interweave the whole. We hope this development serves the honor and benefit of the city. Modern technology should be able to participate in this work. (NZZ, 2 February 1893; see also NZZ, 31 January 1893). ${ }^{19}$

The story of the electrification of Zurich shows the extent to which technological selections depend on political programs, financing possibilities, and preferences in the shaping of public utilities. The city's authorities managed to install an expandable electrotechnical nucleus, to learn the criteria for operating its relatively limited network, and to enlarge it in the following years within the framework of existing and expected sociopolitical conditions.

18 See also the discussion of different strategies for electrification as an expression of a city's political preferences in Todd 1987.

${ }_{19}$ The Neue Zürcher Zeitung had in September 1891 discussed the connection between the "big city of Zurich" and the tramways: "A rational operating of the actual streetcar network and its future amplification is possible only if the network is centrally controlled. This is necessary for the setting-up of an interlocked operating and fares system, and it definitely would be to the detriment of the public that uses the tramway if the different lines were conceded to different parties.... Even if one had a cool or quite hostile attitude to the question of nationalization of the railways, one could eventually conclude it to be more rational and a greater service for the general interest if the tramways were to be operated by the city." NZZ, 10 September 1891 . See also NZZ, 9 September 1891. Similarly, the Schweizerische Bauzeitung: "[Tramways] amplify the cities, develop the surrounding countryside. The benefits obtained through suitably implemented tramways are so big and so concrete that no progress-oriented city should lose time waiting for the system of the future and making it accessible for its inhabitants." 18 March $1893,68$. 
1893 was the first full year of operation for Zurich's new electric plant. The technical and administrative report for this year reveals the extent to which engineers and technicians underwent a continuous learning process. While they tried in the inner city to construct a very simple primary network with only a few transformers, they soon realized that they had to change their strategy in the suburbs. Whereas the inner city showed a locally concentrated, uniform, and constant electricity demand, suburban demand was characterized by a "small number of scattered objects." For the suburbs it was therefore a better strategy "to split the primary lines and construct small, individual transformers" (Wyssling 1894, 40; on "learning by using," see Rosenberg 1982).

A second learning process occurred in the administration of the power plant. "We soon had to fight against the prejudice that our light was prohibitively expensive. . . Manifold instructions, the introduction of discounts, and the chances of an imminent reduction of the ground tax gradually improved the mood" (Wyssling 1894, 41).

Third, statistical observation helped to analyze and optimize the management of the load. Only by operating the plant could one define the effectiveness of its different parts and the variations of electricity demand during the day, the week, and the year; only by operating the networks was it possible to analyze and possibly reduce transmission losses and obtain firm information on prime costs of electricity generation. In the case of Zurich, a first analysis already suggested the abandonment of flat rates for each connected bulb or electric arc and the introduction of meters to define and charge for actual power consumption (ibid., 63).

Finally, the operating board started to promote the use of small electric motors, even though this contradicted the original intentions of the city's electrification commission. "In order to improve the load management during the day, the city council decided at the end of the year to reduce the charge for connecting motors" (Stadtrat von Zürich 1894, 203-4). Small electric motors became a big success. They not only helped to improve the power plant's load factor during the day but also turned out to provide important momentum for the electricity supply's future expansion. This process of "learning by operating" made electricity even more compatible with local political necessities; it also allowed for the steady development of the centralized city's possibilities to offer infrastructural goods.

\section{Conclusion}

Contemporary sources, as well as many historical accounts, claim that electricity supply systems had a great influence on nineteenth-century Swiss society. Some writers even maintain that such influence was "cultural." The present article provides empirical evidence for another interpretation of the relation between society and electricity. Swiss society shaped electrotechnology for the most part as it had already shaped its natural environment during the nineteenth century. In 
fact, electric power networks were made compatible with a more general attempt to dominate nature through technical and systematic means. Nevertheless, "culture" - the habitus, if we accept a different theoretical framework - played an important role in adjusting electrotechnology to the needs and conditions of Swiss society.

On the one hand, such technical phenomena as mapping, hydraulic engineering, the construction and operation of railway, telegraph, and telephone networks, and gas and water supply systems followed the same patterns as did late nineteenthcentury electrotechnology in the administration and domination of time and natural spaces. Those phenomena defined a range of opportunities and the necessary criteria for selecting, interpreting, and classifying new devices, wherever electrification was taking place. The electrification of Zurich shows that the social construction of electrotechnology clearly depended on cultural, political, or habitual patterns; it also shows that these patterns were altered in their turn by feedback derived from the practically determined process of learning by operating and enlarging the first electric nucleus of the city.

On the other hand, the electrotechnical discourse was an equally important directive force in the sociocultural shaping of electrotechnology. The rise of the Swiss electricity supply industry depended on this discourse in two ways. First, fundamental public debates on central issues reassured investors. Periodically they established new patterns of consumption; they also defined at the debate's "closure" (e.g., federal legislation) the direction of the electric supply industry's immediate future. Second, a "base discourse" produced a general competence in dealing with electricity in everyday life through public talks, newsletters, propaganda of the utilities, and exhibitions. Both types of electrotechnical discourse were largely determined by only a few central notions, such as Gemeinnützigkeit, "waterpower as a national good," "modernity," and "progress." These notions provided politicians, administrators, engineers, and investors, as well as the voting and tax-paying public with orientation. They also guided political action and conveyed a sense of security that permitted the remarkable growth rate of the Swiss electric supply industry - for more than a century.

\section{Acknowledgments}

I would like to thank Timothy Lenoir and Cheri Ross for their support and encouragement during my stay at Stanford University, where a preliminary version of this article was presented. I am deeply indebted to Anthony Grafton, Thomas P. Hughes, Rudolf Jaun, Linda Paulson, Ulrich Pfister, Craig Stillwell, and Elena Lazos Chavero for their critical remarks. 


\section{References}

Akten der Kommission für die Vorbereitung des elektrischen Lichtes. 1888-90. Archives of the City of Zurich, V Bc 5.

Allen, Cecil John. 1967. Switzerland - Its Railways and Cable Ways, Mountain Roads and Lake Steamers. London.

Amt für Wasserwirtschaft, ed. 1916. Die Wasserkräfte der Schweiz. Bern.

Amtliches stenographisches Bulletin der schweizerischen Bundesversamlung, Bern. Bauer, Bruno. 1914. "Die Schweizerische Elektrizitäts-Industrie an der Landesausstellung in Bern 1914." Bulletin Schweizerischer Elektrotechnischer Verein 5:289-302, 337-46.

- 1939. "Wasserkraft und Starkstrom." In Die Schweiz im Spiegel der Landesausstellung. Zurich.

Bauer, Hans. 1955. "Eisenbahnverkehr." In Handbuch der Schweizerischen Volkswirtschaft, vol. 1, 367-71. Bern.

Beck, Wilhelm. 1912. Die neuesten Fortschritte auf dem Gebiet der Elektrotechnik. s.l.

Berichte über Handel und Industrie im Kanton Zürich für das Jahr .... 1889, 1895, 1903. Zurich.

Berman, Marshall. 1982. All That Is Solid Melts into Air. New York.

Bernard, Paul P. 1978. Rush to the Alps: The Evolution of Vacationing in Switzerland. New York.

Bertschinger, J. 1914. Das Verhalten gegenüber elektrischen Anlagen. Kilchberg-Zurich.

Bijker, Wiebe E., and John Law, eds. 1992. Shaping Technology/ Building Society: Studies in Sociotechnical Change. Cambridge, Mass.

Bijker, Wiebe E., Thomas P. Hughes, and Trevor J. Pinch, eds. 1987. The Social Construction of Technological Systems. Cambridge, Mass.

Bleuler-Hüni, C. 1903. Die Versorgung des Kts. Zürich mit elektrischer Kraft unter besonderer Berücksichtigung der projektierten Wasserwerkanlagen am Rhein und am Etzel. Zurich.

Bourdieu, Pierre. 1992. The Logic of Practice. Stanford, Calif.

Brändli, Sebastian, et al., eds. 1990. Schweiz im Wandel: Studien zur neueren Gesellschaftsgeschichte. Basel and Frankfurt.

Brulhart, Armand. 1987. Guillaume Henri Dufour: Génie civil et urbanisme à Genève au XIXe siècle. Lausanne.

Burkhard-Streuli, W. 1890. Projekt für die Einführung der elektrischen Beleuchtung in Zürich im Anschluss an die Wasserwerksanlage: Bericht des Stadtingenieurs. Zurich.

Bürkli-Ziegler, Arnold. 1878. Übersicht des Wasserversorgungswesens in der Schweiz, im Auftrag des schweizerischen Ingenieur- und Architekten-Vereins zusammengestellt. Zurich.

-. 1887. Die Elektrische Beleuchtung des Quaigebietes in Zürich. Zurich. 
Bütikofer, Ernst. 1921. Die Elektrizität im Haushalt. Zurich.

Catrina, Werner. 1991. BBC - Glanz - Krise - Fusion: 1891-1991 von Brown Boveri zu $A B B$. Zurich.

Cronon, William. 1991. Nature's Metropolis: Chicago and the Great West. New York.

Dosi, Giovanni, et al., eds. 1988. Technical Change and Economic Theory. London and New York.

Dufour, Guillaume Henri. 1824. La Description du pont suspendu en fil de fer, construit à Genève. Geneva.

Eidgenössische Technische Hochschule. 1955. Eidgenössische Technische Hochschule, 1855-1955. Ecole Polytechnique Fédérale. Zurich.

Eidgenössisches Amt für Verkehr, ed. 1947-64. Ein Jahrhundert Schweizer Bahnen, 1847-1947. Frauenfeld.

Elektrotechnischen Rundschau, Zeitschrift für die Leistungen und Fortschritte auf dem Gebiete der angewandten Electricitätslehre.

Epper J. 1907. Eidgenössisches Hydrometrisches Bureau: Die Entwicklung der Hydrometrie in der Schweiz. Bern.

Exposition Nationale Suisse. 1898. Genève 1896: Rapport Technique publié par ordre du Haut Conseil Fédéral. Geneva.

Fuchs, Carl Johannes. 1910. "Gutachten über eine Stauanlage am Silser See im Antrag der Gemeinden des Oberengandins erstattet." In Vernehmlassung der Oberengadiner Gemeinden zur Frage der Benutzung des Silsersees für ein Wasserwerk im Bergell nach Projekt Zschokke und Lüscher, edited by P. C. Planta. Chur.

Furrer, A. 1892. Volkswirtschafts-Lexikon der Schweiz. Bern.

Gas-, Wasser- und Wärmeversorgung der Stadt Bern, ed. 1993. Von der Gaslaterne zum Erdgas. Wabern-Bern.

Generaldirektion PTT, ed. 1952-1962. 100 Jahre elektrisches Nachrichtenwesen in der Schweiz 1852-1952, 3 vols. Bern.

Graf, Johann Heinrich. 1896. Die Schweizerische Landesvermessung, 1832-1864. Geschichte der Dufourkarte. Bern.

Grossmann, Heinrich. 1918. Die Finanzierungen der Bank für elektrische Unternehmungen in Zürich. Zurich.

Gugerli, David. 1994a. "Der Ausbau der äussern Organisation: Funktionale Differenzierung und diskursive Integration elektrowirtschaftlicher Institutionen in der Schweiz bis 1918." In Allmächtige Zauberin unserer Zeit: Zur Geschichte der elektrischen Energie in der Schweiz, edited by David Gugerli. Chronos: Zurich.

-. 1994b. "Technikbewertung zwischen Öfentlichkeit und Expertengemeinschaft: Zur Bedeutung der Frankfurter elektrotechnischen Ausstellung von 1891 für die Elektrifizierung der Schweiz." In Kontinuität und Krise. Sozialer Wandel als Lernprozess. Beiträge zur Wirtschafts- und Sozialgeschichte der Schweiz, edited by Andreas Ernst et al. Chronos: Zurich. 
-. Forthcoming a. "Für grössere Städte eine unabweisbare Notwendigkeit. Zur infrastrukturpolitischen Modellierung städtischer Elektrizitätsversorgungen in der Schweiz des ausgehenden 19. Jahrhunderts." In Kommunalisierung im Spannungsfeld von Regulierung und Deregulierung im 19. und 20. Jahrhundert, edited by Josef Wysocki.

-. Forthcoming b. "Politics on the Surveyor's Table: The Helvetic Triangulation of Cartography, Politics, and Representation." In Writing/Science, edited by Timothy Lenoir. Stanford, Calif.

-. Forthcoming c. Redeströme und Elektrifizierung. Zur diskursiven Gestalgung einer modernen Technik in der Schweiz (1880-1914). Zurich.

Günthart, A. 1936. Elektrizität und Landwirtschaft. Zurich.

Guyer-Zeller, Adolf. 1896. Das Projekt der Jungfraubahn: Wissenschaftlich, technisch und finanziell beleuchtet. Zurich.

Harvey, David. 1992. The Condition of Postmodernity: An Enquiry into the Origins of Cultural Change. Cambridge, Mass., and Oxford.

Imhof, Alfred. 1925. Die Elektrifikation der Schweizerischen Bundesbahnen. Zurich.

Jegher, A. 1894. Bericht über die Wasserverhältnisse der Schweiz. Bern.

Kern, Stephen. 1983. The Culture of Time and Space: 1880-1918. Cambridge, Mass.

Klöti, Emil. 1905. Die Neuordnung des Wasser- und Elektrizitätsrechtes in der Schweiz: Kritik und Vorschläge. Zurich.

Kopp, R. 1893. Populäre Vorträge über Electricität, gehalten vor dem Heizer- und Maschinisten-Verein Zürich und Umgebung. Andelfingen.

Koselleck, Reinhart. 1975. "Fortschritt."In Geschichtliche Grundbegriffe: Historisches Lexikon zur politisch-sozialen Sprache in Deutschland, vol. 2. Stuttgart.

Kundt, August. 1891. Die neuere Entwicklung der Electricitätslehre. Berlin.

Landry, Jean. 1939. “Coup d'oeil général." In Die Schweiz im Spiegel der Landesausstellung 1939. Zurich.

Lauterburg, Robert. 1876. Versuch zur Aufstellung einer allgemeinen Übersicht der aus der Grösse und Beschaffenheit der Flussgebiete abgeleiteten Schweizerischen Stromabflussmengen. Berne.

-. 1891. Die schweizerischen Wasserkräfte eingetheilt in grössere und kleinere Stromsektionen und berechnet nach der durchschnittlichen Wassermenge der Klein-und Mittel-Wasserstände. Berne.

Lenoir, Timothy. 1992. "Practical Reason and the Construction of Knowledge: The Lifeworld of Haber-Bosch." In The Social Dimensions of Science, edited by Ernan McMullin. Notre Dame, Ind.

Luhmann, Niklas. 1982. The Differentiation of Society. New York.

Lusser, Florian. 1939. "Elektrizitätswirtschaft." In Die Schweiz im Spiegel der Landesausstellung 1939. Zurich.

Maschinenfabrik Oerlikon, ed. 1901. Moderne Apparatenanlagen. Oerlikon.

- 1914. Die Fabrikate der Maschinenfabrik Oerlikon auf der Schweizerischen Landesausstellung. Bern. 
Meili, Friedrich. 1899. Die elektrischen Stark- und Schwachstromanlagen und die Gesetzgebung. Zurich.

- 1900. Der schweizerische Gesetzesentwurf über die elektrischen Stark- und Schwachstromanlagen. Zurich.

Müller, Felix and Jakob Tanner. 1988. "Der Zwang zum Fortschritt." In Solidarität, Widerspruch, Bewegung: 100 Jahre Sozialdemokratische Partei der Schweiz, edited by Karl Lang et al. Zurich.

Nelson, Richard R., and Sidney G. Winter. 1982. An Evolutionary Theory of Economic Change. Cambridge, Mass.

Peters, Tom F. 1987. Transitions in Engineering: Guillaume Henri Dufour and the Early Nineteenth-Century Cable Suspension Bridges. Basel and Boston.

Pfleghart, A. 1904. Das Recht zur Erstellung elektrischer Leitungen nach der schweizerischen Bundesgesetzgebung. Basel.

Pinch, Trevor J., and Wiebe E. Bijker. 1987. "The Social Construction of Facts and Artifacts: Or How the Sociology of Science and the Sociology of Technology Might Benefit Each Other." In The Social Construction of Technological Systems, edited by Wiebe E. Bijker, Thomas P. Hughes, and Trevor J. Pinch. Cambridge, Mass.

Protokoll und Akten der grosstadträtlichen Kommission betr. Einführung der elektrischen Beleuchtung 1890, Archives of the City of Zurich, V Aa 141.

Rosenberg, Nathan. 1982. "Learning by Using." In Inside the Black Box, edited by Nathan Rosenberg. Cambridge.

Schär, Oskar. 1905. Die Verstaatlichung der schweizerischen Wasserkräfte. Basel. Schilling. 1885. Bemerkungen über den gegenwärtigen Stand der elektrischen Beleuchtung im Auftrage des Aufsichtsrathes der Gasbeleuchtungs-Gesellschaft für die Generalversammlung der Actionäre am 26. September 1885. Munich.

Schivelbusch, Wolfgang. 1983. Lichtblicke: Zur Geschichte der künstlichen Helligkeit im 19. Jahrhundert. Munich.

Schmidt, Aurel. 1990. Die Alpen: Schleichende Zerstörung eines Mythos. Zurich.

Schweizerische Bauzeitung. Wochenschrift für Bau-, Verkehrs- und Maschinentechnik. Organ des Schweizerischen Ingenieur- und Architecten-Vereins und der Gesellschaft ehemaliger Studirender des eidgenössischen Polytechnikums in Zürich. 1883. Carouge-Genève.

Seitz, Gabrielle. 1987. Wo Europa den Himmel berührt: Die Entdeckung der Alpen. Munich.

Siegenthaler, Hansjörg. 1993. Regelvertrauen, Prosperität und Krisen: Die Ungleichmässigkeit wirtschaftlicher und sozialer Entwicklung als Ergebnis individuellen Handelns und sozialen Lernens. Tübingen.

Silverberg, Gerald. 1988. "Modelling Economic Dynamics and Technical Change: Mathematical Approaches to Self-Organisation and Evolution." In Technical Change and Economic Theory, edited by Giovanni Dosi et al. London and New York.

Stadelmann, Kurt, and Thomas Hengartner. 1994. Ganz Ohr: Telefonische Kommunikation. Bern. 
Stadtrat von Zürich. 1894. Geschäftsbericht des Stadtrates der Stadt Zürich: Elektrizitätswerk. Zurich.

Stiefel, E. 1935. Werbetätigkeit städtischer Elektrizitätswerke. Zurich.

Tanner, Albert. 1988. "Bürgertum und Bürgerlichkeit in der Schweiz: Die 'Mittelklassen' an der Macht." In Bürgertum im 19. Jahrhundert: Deutschland im europäischen Vergleich, edited by Jürgen Kocka. Munich.

Todd, Edmund N. 1987. "A Tale of Three Cities: Electrification and the Structure of Choice in the Ruhr, 1886-1900." Social Studies of Science 17:387-412.

Vereinigung exportierender Elektrizitätsunternehmungen. 1976. 50 jähriges Bestehen der Vereinigung exportierender Elektrizitätsunternehmungen: 19261976. Lausanne.

Vischer, Daniel. 1986. Schweizerische Flusskorrektionen im 18. und 19. Jahrhundert. Zurich.

—. 1988. "125 Jahre Hydrometrie auf Bundesebene: Die Rolle des Ingenieurs Robert Lauterburg." Schweizer Ingenieur und Architekt 43:1184-91.

Walter, François. 1990. Les Suisses et l'environnement. Carouge-Genève.

Wasser- und Elektrizitäts-Werkes Romanshorn. 1899. Dritter Jahresbericht und Rechnung. Romanshorn.

Weber, H. F. 1884. Schweizerische Landesausstellung Zürich 1883: Bericht über Gruppe 32: Physikalische Industrie: Wissenschaftliche Instrumente. Zurich.

Wyss, Anton. 1964. Die Entwicklung der Finanzierung in der schweizerischen Elektrizitätswirtschaft. Basel.

Wyssling, Walter. 1894. "Einige Resultate vom Bau und Betrieb des Electricitätswerks der Stadt Zürich." Jahrbuch des Schweizerischen Elektrotechnischen Vereins, 5.

- 1946. Die Entwicklung der Schweizerischen Elektrizitätswerke und ihrer Bestandteile in den ersten 50 Jahren. Zurich.

Zängl, Wolfgang. 1989. Deutschlands Strom: Die Politik der Elektrifizierung von 1866 bis heute. Campus: Frankfurt and New York.

Ziegler, Willy Heinrich. 1937. Die wirtschaftliche Entwicklung der A.G. Brown, Boveri \& Cie., Baden, des Brown-Boveri-Konzerns und der A.G. MotorColumbus. Brugg.

Zimmerman, Andrew David. 1992. "A Political History of Electricity in the USA," Ph.D. diss., University of Delaware.

Zollikofer, H. 1928. Notizen zur Geschichte der schweizerischen Gasversorgung und Gasindustrie. Zurich.

Swiss National Foundation for Scientific Research Department of History University of Zurich 